\title{
Bilinçaltı Reklamcılık ve Tüketicilerin Satın Alma Niyetine Etkisi ${ }^{*}$
}

\author{
The effect of subliminal advertising on consumer buying intentions
}

\author{
Mehmet MARANGOZ ${ }^{1 \text { a }}$ \\ Ayşe Gülgün IŞLI ${ }^{2}$
}

\begin{abstract}
${ }^{1}$ Muğla Sttkı Koçman Üniversitesi, İktisadi ve İdari Bilimler Fakültesi, Muğla. mehmetmarangoz@mu.edu.tr ${ }^{2}$ Muğla Sıtkı Koçman Üniversitesi, Sosyal Bilimler Enst. İşletme ABD Doktora Öğrencisi, Muğla. ayse-isli@hotmail.com a Yazışılan yazar/Corresponding author
\end{abstract}

\begin{abstract}
Özet
Bu çalışma bilinçaltı reklamcılı̆̆ı duyguları tetikleyerek tüketicilerin satın alma niyetine bir etki yaratip yaratmadı̆̆ını ortaya koymayı amaçlamaktadır. Bir kopyasında gülen yüz görseli, bir kopyasında kızgin yüz görseli gizlenen iki bilinçaltı reklam afişi oluşturulmuş; afişe uygun 4 demografik, 30 duygular üzerine ve 4 satın alma niyeti olmak üzere toplam 38 sorudan oluşan anket formu 300 kişide yapılmış ve değerlendirilmiştir. Gülen yüz görselinin bulunduğu reklam afişine maruz kalan katılımcıların; yas ve eğitim düzeyinin tüketicilerin satın alma niyetine etki ettikleri görülmüş, ayrica görselin sıcak duygular tetikleyerek, tüketicilerin satın alma niyetini olumlu yönde etkilediği ortaya çıkmıştır. Kızgın yüz görselinin bulunduğu reklam afişi için; demografik unsurlarm tüketicilerin satın alma niyetine etkisi görülmemiş, bununla beraber görselin negatif duygular tetikleyerek, tüketicilerin satm alma niyetine olumsuz yönde etki ettiği görüşmüştür.
\end{abstract}

Anahtar kelimeler: Bilinçaltı, Bilinçaltı reklam, Satın alma niyeti

JEL kodlart: M31, M37

\begin{abstract}
The aim of this study is to examine of subliminal advertising on consumer's intention to purchase. Two subliminal advertising's banners is prepared; in the one copy that is hidden a smiley face and in the other copy that is hidden an angry face. A total of 38 questions, consisting of 4 demographics, 30 emotions and 4 purchasing intentions, were made and evaluated for 300 participants. The result of the banner advertising that has a smiley face visual; purchase intensions are changing due to age, education level. In addition, to be given warm senses that in the subliminal advertising's banner affects in a positive way. The result of the banner advertising that has an angry face visual; purchase intensions are not changing due to demographic variables. The fact remains that to be given warm senses that in the subliminal advertising's banner affects in a nagative way on consumer's intention to purchase.
\end{abstract}

Keywords: Subconscious, Subliminal advertising, Intention to purchase

JEL codes: M31, M37

\footnotetext{
* Bu makale, Ayşe Gülgün İŞLİ'nin Muğla Sıtkı Koçman Üniversitesi Sosyal Bilimler Enstitüsü tarafından kabul edilen “Pazarlama İletişim Aracı Olarak Bilinçaltı Reklamcılık ve Tüketicilerin Satın Alma Niyetine Etkisi Üzerine Bir Araştırma" isimli yüksek lisans tez çalışmasından üretilmiştir.
} 


\section{GİRIŞ}

Reklam, tüketicileri mevcut veya piyasaya yeni sürülen ürünlerden haberdar ederek ve özellikle de bunların nitelik ve yararlarına dair potansiyel kullanıcıları eğiterek avantaj sağlamaya çalışmakta kullanılan bir araçtır. Reklamcılara bu konuda büyük iş düşmektedir. Mesajı oluştururken hedefledikleri asıl olgunun tüketici tarafından ilgi görmesine, akılda kalmasına ve olguyu tüketim davranışına dönüştürmeye yönelik çalışmalar yapmalıdırlar.

Bilinçaltı reklamcılık günümüzde en etkili reklam yöntemlerinden birisi olarak mesaj, iletilmek istenen olguyu, tüketicide bilinçli bir şekilde olmadan meydana getirmeyi hedeflemektedir. Çeşitli psikolojik, kültürel, toplumsal, coğrafik ögeler kullanılmakta ve böylelikle bireye mesajın doğrudan değil dolaylı olarak iletilmesi sağlanmaktadır. Çalışmada bilinçaltı reklamcılık literatürünün, satın alma niyeti ile duyguları bir arada inceleyen araştırmalara olan ihtiyaç dikkate alınarak, bilinçaltı reklamın tüketicide uyardığı duyguların satın alma niyetine etkisi olup olmadığı incelenmektedir. Bu amaçla bilinçaltı reklamcılıkta kullanılan yöntemler esas alınarak hazırlanan afişler ile verilmek istenen bilinçaltı mesajların tüketicilerin satın alma niyetine etkisi ortaya konmaktadır.

\section{BİLINÇALTI VE BİLINÇALTI REKLAMCILIK KA VRAMLARI}

"Subliminal" ve "eşikaltı" şeklinde de ifade edilen bilinçaltı kavramını ortaya atan Sigmund Freud, psikanaliz kuramında bu kavramı ele almaktadır. Freud'a göre bilinç dediğimiz yapı hem görülen bilinçten hem de daha altlarda, görünmez yerlerde var olan başka bir yapıdan oluşmaktadır. Burası bilinçaltıdır ancak bilinci etkileyen asıl güç bu yapıda bulunmaktadır. Erich Fromm (1950)'a göre, ise bilinçaltı kavramı gizemli bir kelimedir. Bilinçaltı diye bir şey yoktur; yalnızca bilincinde olduğumuz ve olmadığımız davranışlarımız bulunmaktadır. İşte bu bilincinde olmadığımız davranışlara bilinçaltı denmektedir (Dobrenkov, 1979: 91).

Jung (1918)'a göre, dışadönük ya da içe dönük bir davranışın ve işlevin gelişmesi; yaşantının, kişinin kendi dünyasını ılımlı kılma, kendisinden bir iz bırakabilme sürecinin bir parçasıdır. Dıştan güçlü bir engel gelmedikçe kişi, kendisine kolay ve içten gelen gelişim sürecini yaşamaktadır. Toplumsal baskı, sosyal çevre ya da alınan eğitimler gibi birçok sebepten dolayı, kabul edilen davranış biçimlerine uyma eğilimi gösterilmektedir. Bu süreç içerisinde doğrudan kişiliğe ilişkin birçok şey bilinçaltına itilmekte, psikolojideki adıyla bastırılmaktadır. Bu bastırılmış eğilimler, kişisel bilinçaltına aittir ve sanılanın aksine unutulup gitmezler, bir bahçenin bir köşesinde bitiveren umursanmamış yabani otlara benzemektedirler (Fordham, 2015: 57-58).

Bilinçaltında itilmiş birçok imge ya da mesaj kişilerin günlük hareketlerini, konuşmalarını, davranışlarını, ilişkilerini etkilemekte, kişi farkında olmadan bilinçaltının yönlendirmesiyle hareket etmektedir. Tüketim konusunda da aynı durum geçerlidir. Tüketicilerin tercihleri, satın alma niyetleri, tutum ve inançları, satın alma davranışları bilinçaltında yer aldığından dahi haberleri olmadıkları mesajlardan etkilenmektedir.

Geçmişten günümüze bilinçaltı konusu üzerine yapılmış araştırmalardan yola çıkılarak, kavramın, bilinçaltına mesaj yollamak suretiyle satış yapmak ya da mevcut satışları artırmak için pazarlama alanına dahil edilmesi bilinçaltı reklamcılığı doğurmuştur. Bilinçaltı reklamlarla insanların reklamlarda gördükleri mesajlara direnmeden ya da karşıt bir düşünce geliştirmeden kabullenmeleri ve reklamın belirlediği şekilde bir davranış 
değişikliğine gitmeleri hedeflenmektedir. Bilinçaltı reklam, reklam ortamları kanalıyla yapılan tanıtımlarda, algılama eşiğinin altında kalan birtakım uyaranlarla bilinçaltını hedefleyen reklam mesajlarının oluşturulması şeklinde ifade edilmektedir. Bilinçaltı reklamda hedef, bilinçaltı mesajlar yoluyla bilinçaltı iknayı gerçekleştirmektir. Bilinçaltı reklam kişilerin gördüklerinin ya da duyduklarının, farkında olamadıkları uyaranlar tarafından yönlendirilmesine ve bu etkinin bilinç düzeyine çıkıp ürüne ya da hizmete karşı davranış geliştirmesine neden olmaktadır (Sungur, 2007: 178).

\section{BİLİNÇALTI MESAJLAR VE TEKNIKLERI}

Bilinçaltı reklamları izleyen kişilerin reklamı yapılan markanın, ürünün ya da hizmetin farkında olduğu bir gerçektir. Farkında olmadıkları ise reklamların içine yerleştirilmiş olan ve onların bilinçaltlarını uyaran bilinçaltı mesaj, bilinçli algı düzeyimizin altında tutulan ve sadece zihnimizin tespit edebileceği duyu organlarımıza seslenen mesajlar olarak ifade edilmektedir (Bilen, 2013: 45).

Bilinçaltı reklamcılığın temelinde bilinçaltı mesajlar yatmaktadır. Bilinçaltı mesaj, bilinçaltını etkilemeyi amaçlayan resim, imge, görüntü, ses ve her türlü mesajlara verilen isimdir ve bilinçaltı mesajlarda, bir tema belirlemek veya bir konuyu işaret etmek için her seferinde farklı bir kod oluşturulması gerekmektedir. Kodların oluşturulmasında arketip ve imge kullanılarak hedef kitle ikna edilmeye çalışılmaktadır.

\section{1. İkna}

Çeşitli iletişim çalışmaları sonucunda ortaya çıkan fikir, tutum ve davranışlardaki değişiklik şeklinde ifade edebileceğimiz ikna, tanımında belirtildiği gibi, alıcının davranışını istenilen yönde ilerletebilmek amaciyla uygulanan bir yöntemdir (Türkkan, 2000: 21). İkna edici iletişimi uygulamanın; hedef kitlede yeni bir tutum ortaya çıarmak, hedef kitlede var olan tutumun şiddetini artırmak, hedef kitlenin var olan tutumunu değiştirmek şeklinde üç sebebi bulunmaktadır (Kağıtçıbaşı, 1988:167). Aristo'ya göre, ikna edilen ile ikna eden, ortak bir paydada buluşturulursa ikna gerçekleştirilebilmektedir. İkna etmeye çalışan tarafın yapması gereken, bu ortak paydayı bulup, karşı tarafın davranışlarını önceden kestirmek ve buna göre önlemler almaktır. Ortak payda içerisinde, kişinin sadece ihtiyaçları değil istekleri hesaba katılmalıdır. Bilinçaltı mesajlar konusunda hedef kitlenin ikna edilmesi ise 'gizli ortak payda' yani arketipler ile açılanabilmektedir (Darıcı, 2013: 13).

\subsection{Arketipler}

Arketipler her insanın DNA'sına işlemiş ve kalıtsal olarak da yeni nesillere geçmeye devam eden varoluşsal kod olarak adlandırılmaktadır. Evrensel bir kavram ve durum sayılabilecek ölçüde süreklilik taşıyan ilk imge, karakter ya da kalıp demektedir. Arketipler, Jung'un öne atmış olduğu kolektif bilinçaltını oluşturan öğelerdir (Darıcı, 2013: 77). Bilinçaltını ifade yolu olarak bilinen arketipler kişileştirilmiş ve sembolik biçimlerde görülmektedirler. Tablo 1'de bazı arketiplerin örnek markalar üzerinden insanlara etkileri görülmektedir. 
Tablo 1. Arketipler ve İnsanların Hayatlarındaki Temel Fonksiyonları

\begin{tabular}{lll}
\hline Arketipler & Insanlara etkisi & Örnek Marka \\
\hline Yaratıcı & Yeni bir şey yaratma & Apple \\
\hline Anne & İlgilenme & Sana \\
\hline Hükümdar & Kontrol sağlama & Microsoft \\
\hline Soytarı & İyi vakit geçirme, eğlenme & Pepsi \\
\hline İçimizden biri & Olduğu gibi iyi hissetme & Fanta \\
\hline Aşık & Aşkı bulma ve sunma & Cornetto \\
\hline Kahraman & Cesur hareket etme & Nike \\
\hline Asi & Kuralları bozma & Harley-Davidson \\
\hline Sihirbaz & Dönüşümü gerçekleştirme & Red bull \\
\hline Masum & Innancı koruma, yenileme & Coca cola \\
\hline Kaşif & Bağımsılığı koruma & Levi's \\
\hline Bilge & Dünyalarını anlama & Discovery Channel \\
\hline
\end{tabular}

Kaynak: Borça, Güven. Marka Sunumu. İstanbul: 2013.

Nörologlar, insan bilincinde meydana gelen değişimleri ve hareketleri incelemek için 'İşlevsel Manyetik Rezonans Görüntüleme' yöntemini kullanmaktadırlar. Kısaca FMRI denilen bu teknolojide, arketiplerin etkisini gözlemleyebilmek amacıyla, FMRI cihazı ile yapılan beyin tarama çalışmalarında deney gruplarına, bir insanın doğumundan ölümüne kadar olan değişik fotoğraf kareleri izletilmiş, en fazla zihinsel tepkinin ise doğum ve ölüm olaylarına verildiği ortaya çıkmıştır. Bununla beraber, cinsellik içeren reklam filmlerinin diğer reklam filmlerine oranla beynin daha fazla bölgesini uyardığı sonucuna varılmıştır. Dolayısı ile film ve reklam sektöründe bu arketipleri temsil eden imgelerin, sembollerin, yazıların ve diğer çağrıştırıcıların film, reklam ya da ürün hatırlama konusunda etkisi bulunmaktadır denilebilmektedir (Küçükbezirci, 2013: 10).

\section{3. İmgelem}

İmgelem, duyularımız aracılığıyla zihinlerimizde temsili bir anlam yaratma süreci olarak kabul edilmektedir. Zihnimizde bir şeyi resmettiğimizde, o şeyin nasıl göründüğünü, verdiği hissi, tadının nasıl olduğunu hayal ettiğimizde imgelem ortaya çıkmaktadır. Yani imgelem için, kişilerin düşsel kabiliyetine ve hayal dünyasına bağlı, düşünce ve duyguların yerine geçen işaretler dizisidir demek doğru olacaktır. Araştırmalar bir şeyi hayal ettiğimiz zaman, genellikle etkisinin olumlu ve daha kalıcı olduğunu ortaya koymaktadır. İmgelemin bilinçaltı reklamcılıkta önemli bir yere sahip olmasının sebebi de budur (Kapar, 2009: 4).

Zihinde canlandırma ve imgeleme bilinçaltı mesajlarda beynin çalışma tarzı ve biçimi dikkate alınarak uygulanmaktadır. Televizyonda film seyrederken dramatik bir sahnede gözden yaş gelmesi ya da korku sahnesinde birden irkilmek insanların yaşadığı doğal anlardır. İstemsizce verdiğimiz bu tepkiler, filme ya da izlenen görsele çok fazla odaklanmamızın sonucu bilincin devre dışı kalmasından kaynaklanmaktır. Ekrana bu denli dikkat kesilmek bilincin kendini çevreye kapatmasına sebep olmaktadır. Ve bilinç, o sırada her türlü bilinçaltı uyarana açık konuma gelmektedir. İşte imgelemler bu noktada devreye girmekte, genellikle bu tarz sahnelerde "ansal kurgu" yöntemi dediğimiz yöntemle bilinçaltına sunulmaktadır. Ansal kurgu sırasında hareketli görüntünün süresinin kısa tutulmasından dolayı beyin, o sürede anlamlandıramadığı (genellikle cinsellik ve korku öğeleri) görüntüyü çözümlemek üzere değerlendirmeye almaktadır. Bu sırada bilinçaltı, 
mesajı almakta ve depo etmektedir. Mesajın sunulduğu imgelemin içeriğindeki marka film ya da fikir, duygularımızı harekete geçirmek üzere doğum ya da ölüm arketipine bağlandıktan sonra hele ki sık tekrar yapıldıktan sonra bilinçaltından çıkartılması neredeyse imkansız olacaktır (Darıc1, 2013: 33-34).

\section{BİLINÇALTI REKLAMCILIK VE DUYGU}

Eskiden tüketicilerin sadece rasyonel karar vererek satın alma kararı aldığı düşünülmekteydi. Yapılan araştırmalar sonucunda ise reklamcılar, insanların rasyonel kararlardan çok duygusal kararlar alarak satın alma davranışında bulunduklarının farkına varmışlardır (Koç, 2013:231).

Duygular kullanılarak hazırlanan reklamlarda amaç, tüketiciyi ani bir kararla düşünmeden, detaylı bir araştırma süresi tanımadan, gönderilen duygularla satın alımın gerçekleşmesini sağlamaktır. Reklamcılık tüketicilerde çeşitli duyguların canlandırılmasını ve bu yolla ikna edilmesini hedefler. Bu amaçlarla reklam stratejisi doğrultusunda reklam içeriklerinde çeşitli duyguları uyarmaya yönelik çekicilikler kullanılır; mizah çekiciliği, korku çekiciliği, sıcaklık çekiciliği ve müzik kullanımı (Moriarty, 1991, Aktaran; Uztuğ, 2003: 206-207) gibi.

\section{BİLINÇALTI REKLAMCILIK VE ETKİLERI}

Bilinçaltı reklama maruz kalan tüketicilerin; inanç ve tutumları, verilen mesaja güvenleri ile satın alma niyetleri verilmek istenen mesajdan etkilenmektedir. Tüketicide satın alma niyeti oluşturabilmek için verilen mesajın tüketicinin inanç ve tutumunda olumlu etki yaratması ve mesaja güvenin artırılması önemlidir.

\section{1. İnanç ve Tutumlar}

Tutum, insanlara ve onların bir obje ile ilgili psikolojik, düşünce, duygu ve davranışlarını bir bütün olarak etkileyen eğilimdir (Kağıtçıbaşı, 1988: 84). Tutumlar, bilişsel, duygusal ve davranışsal olmak üzere üç ögeyi ele almaktadır. Duygusal öge, çevre ile ilgili duyum, bilgi ve siniflandirma ve bu kategorilerin olumlu, olumsuz durumlarla ya da istenmeyen sonlarla ilişkilendirilmesini sağlamaktadır. İnsanların tutum konusunda olumlu ya da olumsuz duygular hissetmesi önceki deneyimlerine bağlı olmakla birlikte; duygusal öğe insanların değerler sistemi ile de yakından ilgilidir. Bilişsel öge, uyarıcılar ile ilgili gerçeklerle ilgilenen bilgi ve inançları barındırmaktadır. Tutum kavramı ile ilgili bilgi edinmek, insanların bir konu ile ilgili öncesinde deneyim sahibi olması sonucu gerçekleşmektedir. Davranışsal öge, insanların bir uyarıcı hakkındaki tutumunu davranış eğilimine dönüştürmesiyle ilgilidir. Bahsedilen davranış eğilimleri, söz ile ya da başka hareketler ile anlaşılabilmektedir. Yani, belli bir tutumun varlığ1 ancak insanların yansıttığı düşünülen birtakım gözlemlenebilen davranışlardan anlaşılabilmektedir (İnceoğlu, 1993: 16-17).

Tutum kelimesi birçok kavramla bütünlük sağlamaktadır. Bunlardan en önemlisi de inanç kavramıdır. İnanç, insanın bir şeyler hakkında kabul etmiş olduğu ya da onay vermiş olduğu tanımlayıcı, tamamlayıcı düşünceler bütünüdür (Kotler, 1997: 187). İnanç, tutumların bilişsel ögesinde bulunmakta, duygusal ögeyle birleşimi ile de tutuma dönüşmektedir. Fakat belirtmek gerekir ki her inanç tutuma dönüşmemektedir. İnançlar insanların, ürünler ve sunumları hakkındaki düşünceleri ile yakından ilgilidir ki inançlar, ürün ve marka imajlarını oluşturmaktadırlar. Dolayısıyla işletmelerin, kendilerine karşı edinilmiş birtakım olumsuz ve satın alınmayı engelleyen inançlar varsa onları olumlu yöne çekmek için bir şeyler yapmaları 
gerekecektir. Çünkü inanç ve tutumlar çeşitli eylemlerle şekillenip, satın alma davranışına etki etmektedirler (Yükselen, 2003: 104).

\subsection{Mesaja Güvenilirlik}

Güven kavramı tutumda olduğu gibi bilişsel, duyuşsal ve davranışsal olarak bütünsel ele alınmalı ve bu kavramın disiplinler arası bir kavramdır. Pazarlama ve reklamcılık alanında güven, tüketicinin maruz kaldığı reklamdaki mesajın doğru olduğuna inanması, şüphe barındırmaması şeklinde ifade edilmektedir. Ayrıca tüketicinin reklama duyduğu güven ile ikna olması arasında doğru orantı bulunmaktadır (Soh, 2009: 83).

\subsection{Satın Alma Niyeti}

Satın alma niyeti tüketicinin uyaranlara karşı, belirleyici tepkisini ortaya koyduğu kritik bir aşamadır (Tek, 1999: 215). Çünkü, tüketicide satın alma niyeti oluşturmayı başarabilen işletmeler, prestij, sadakat ve rekabet gücü konusunda büyük adım atmış olacaklar ve piyasadaki konumlarını sağlamlaştırabileceklerdir.

Satın alma niyeti üzerine yapılan araştırmalara göre, tüketicilerin satın alma niyetlerini olumlu yönde en çok etkileyen özelliğin resimler olduğu ortaya çıkmıştır. Reklamlarda yer alan tanıdık resimlere maruz kalan tüketicilerin daha olumlu tepkiler verdiği ve bu tepkilerin de tüketicilerin reklama ya da markaya karşı tutumunu olumlu yönde etkilediği anlaşılmıştır. Ancak burada resmin boyutu ve gösterim süresi de dikkat edilmesi gereken hususlardır. Örneğin tüketicilerin bir resme on beş saniyenin üstünde maruz kalması dikkatleri dağıtacak, tüketicinin resmi değiştirmek istemesine sebep olacaktır (Cüceloğlu, 2012: 36).

\section{ARAŞTIRMA TASARIMI VE YÖNTEMI}

Araştırma için özel olarak, içerisine gülen yüz ve kızgın yüz gizlenmiş bilinçaltı reklam afişleri hazırlanmıştır. Afişlere uygun oluşturulan anket formunda iki bağımsız değişken; cinsiyet, yaş, eğitim ve gelir olmak üzere 4 demografik ifade, sıcak ve negatif olmak üzere 30 duygu ifadesi yer almaktadır. Bağımlı değişken olarak 4 satın alma niyeti ifadesi ile anket tamamlanmaktadır. Hazırlanmış olan ankette duygu ve satın alma niyeti ölçeklerinin esas dili İngilizce olduğu için 49 kişi ile gerçekleştirilen bir ön test çalışması yapılmıştır. 5'li Likert ölçeğinde yer alan "yoğun hissediyorum/hissetmiyorum" kategorilerinde yer alan "yoğun" ifadesi katılımcılarda kafa karışıklığına sebep olmuş; yerine "çok hissediyorum", "hiç hissetmiyorum" ifadeleri kullanılarak anket formu son haline getirilmiştir.

Araştırmanın kapsamı olarak ana kütleyi iyi temsil edebilmesi amacıyla araştırmaya seçilecek olan tüketicilerin farklı sosyo-ekonomik ve sosyo-kültürel özelliklerde olmalarına özen gösterilmiş, 18 yaş ve üstü 300 kişiye afiş gösterilmiş ve ardından yüz yüze anket uygulaması gerçekleştirilmiştir. Araştırmanın ana kütlesine bir kısıtlama getirilmemiş olup Türkiye'nin çeşitli illerinde (Muğla, Aydın, İzmir, Denizli, Ankara, İstanbul) ikamet eden 300 tüketici ile Şubat 2016 - Mayıs 2016 tarihleri arasında yüz yüze anket uygulaması gerçekleştirilmiştir. Tokol (1994) yapılan araştırmada ana kütleyi oluşturan bireylerin çok sayıda olması aynı zamanda süre ve maliyet kısıtının olması, örnekleme yöntemi olarak tesadüfi olmayan örnekleme yöntemlerinden kolayda örnekleme yönteminin uygulanmasını gerektirmiştir. Veriler toplandıktan sonra istatistik programında analiz yapılarak sonuçlar 
yorumlanmıştır. Anket sonuçları doğrultusunda iki afişin satın alma niyetine etkileri ayrı ayrı ele alınmıştır.

Bilinçaltı reklamların daha çok görme duyumuza hitap etmesinden dolayı, çalışmada; reklam aracı olarak basılı yayın araçlarından afiş tercih edilmiş, bunun için özel olarak hazırlanan özgün afişin alınan iki kopyasına ayrı iki görsel (gülen/kızgın yüzler) eklenerek amaca uygun materyal hazırlanmıştır (Afişler EK 1 ve EK 2' de verilmiştir). Bu afişlere uygun anket soruları ile araştırma gerçekleştirilmiştir (Anket EK 3'te verilmiştir).

Bilinçaltı reklam afişi oluşum aşamasında duyguları ele alan ve Morris (1995) tarafından oluşturulan SAM (öz değerler mankeni) adında bir derecelendirme formu örnek alınmıştır. SAM, gülen, nötr, üzgün ve kızgın insan figürlerinden oluşan bir derecelendirme formudur.

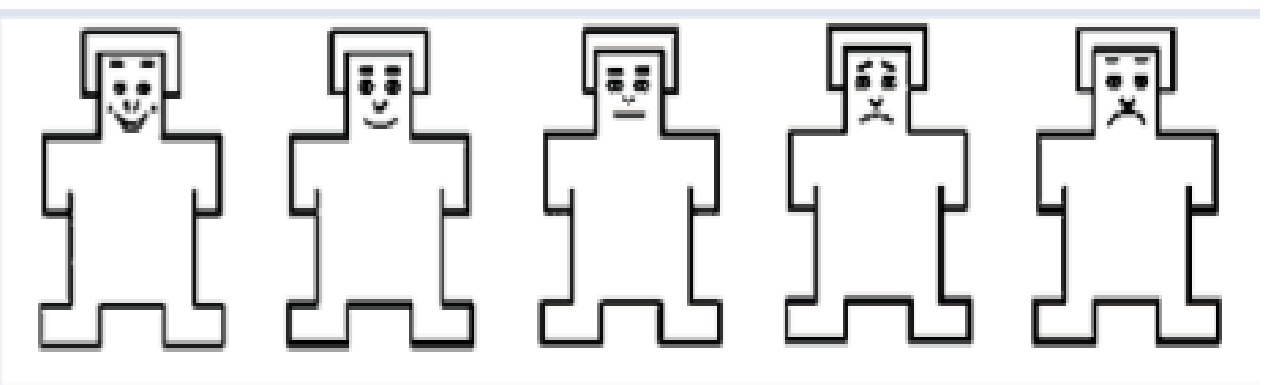

Şekil 1. Öz Değerlendirme Mankeni

Kaynak. Morris, Observations: SAM: The Self-Assessment Manikin; An Efficient CrossCultural Measurement of Emotional Response, 1995, s.64

Şekil 1'de görülen insan figürlerinin, reklama karşı insanların ilgisini canlı tutmada etkili olduğu ortaya çıkmıştır. Hem bu sebepten dolayı hem de yaş, kültür ve dil farkı gözetmeyen bir ölçüm olmasından dolayı bilinçaltı reklam afişi hazırlamada gülen ve kızgın yüz figürleri tercih edilmiştir. Forma uygun olarak yapılan ölçek araştırması sonucunda Edell ve Burke (1987)'nin tüketicilerin reklamlardan dolayı sahip olduğu hislerini eğlenceli, sıcak ve negatif duygular olmak üzere üç grupta özetlediği çalışmaları, bu araştırmaya referans olarak alınmıştır. Reklamların, şirketler tarafından oluşturulması esnasında tüketicilerde yaratılmaya çalışılan duygulara odaklanılmasından öte, tüketicilerin reklamlara maruz kaldığı anda nasıl hissettiği üzerinde yoğunlaşmıştır. Edell ve Burke'nin (1987) yapmış olduğu çalışma reklamların tüketicilerde oluşturduğu duyguları ortaya çıkarmakta etkili olacak şekilde tasarlanmış; ancak tüketim deneyimi esnasındaki spesifik duyguları ölçmek için tasarlanmamıştır. Satın alma niyeti ölçeği Stafford (1998) tarafından ortaya konmuştur ve tüketicilerin kendilerine sunulmuş olan ürün ya da hizmete yönelik eğilimlerini ölçmek amaçlanmıştır. Farklı kullanım şekilleriyle çalışmalarda yer alan satın alma niyeti ölçeği ifadeleri çalışmaya uygun olarak gözden geçirilmiş ve uyarlanmıştır.

Afişin oluşumundan sonraki aşamada renkler ve insanlara etkileri dikkate alınarak hazırlanan afişte uyarıcı etkisinden dolayı sıcak renklerden "turuncu" tercih edilmiştir. Çünkü turuncu ne kırmızı kadar agresif ne de sarı kadar neşeli bir mesaj vermektedir. İki rengin karışımından meydana gelen turuncunun; iştah açıcı özelliği olduğu gibi, şiddete yönelik uyarıcı etkisi de bulunmaktadır. Yani ağırlıklı olarak tek bir duyguyla sınırlı kalmayan ve bilinçaltı reklam afişiyle ölçülmek istenen sıcak ve negatif duyguları içinde barındıran turuncu rengi, afişin fonu için en uygun renk olarak düşünülmüştür. Turuncu 
zeminin üzerine yerleştirilen "süt" yani beyaz renk; hafiflik, nötrlük ve soğukluk hissi verdiği için tercih edilirken, yine etkiyi dengelemek adına, üzgün, melankolik ve nötr olma hislerini barındıran kahverengi olan "çikolata" reklamı yapılacak ürün olarak tercih edilmiştir.

\section{ARAŞTIRMA BULGULARI}

Çalışmanın bulgularında araştırmaya katılan tüketicilerin demografik özelliklerine, demografik özelliklerin, sıcak ve negatif duyguların satın alma niyetine yönelik ölçek güvenilirliği için Cronbach Alfa güvenilirlik analizi, frekans ve yüzde dağılımları ve nominal lojistik regresyon analizi yer almaktadir. Sicak $(0,92)$ ve Negatif $(0,93)$ duygu ifadelerinin güvenilirlik sonucu $(0.80 \leq \alpha<1.00$ arasında yer aldığ 1 için) anket formunda yer alan duygu ölçeği yüksek derecede güvenilirdir. Satın alma niyeti ifadelerinin güvenilirlik sonucu Cronbach Alfa katsayısı (0,74; $0.60 \leq \alpha<0.80$ değerleri arasında yer aldığından) anket formunda yer alan satın alma niyeti ölçeğinin oldukça güvenilir olduğu görülmektedir.

Araştırmaya katılan tüketicilerin demografik dağılımlarına bakıldığında, cinsiyetlerinin $\% 50$ 'sinin kadın \%50'sinin erkek oldukları, \%27,7'sinin 24-30 yaş aralığında ve lisans mezunu oldukları görülmektedir. Gelir düzeyleri ise 1001-2000 ve 2001-3000 olan katılımcıların çoğunlukta oldukları görülmektedir. Ayrıca demografik özellikler ile gülen yüz ve kızgın yüze ilişkin bulgular Tablo 2'de görülmektedir.

Tablo 2. Demografik Değişkenler ile Gülen Yüz ve Kızgın Yüz Frekans Analizi

\begin{tabular}{|c|c|c|c|c|c|c|c|c|c|}
\hline \multirow{3}{*}{\multicolumn{2}{|c|}{ Değişkenler }} & \multicolumn{4}{|c|}{ Gülen Yüz Görseli } & \multicolumn{4}{|c|}{ Kızgın Yüz Görseli } \\
\hline & & \multicolumn{2}{|c|}{ Niyet Yok } & \multicolumn{2}{|c|}{ Niyet Var } & \multicolumn{2}{|c|}{ Niyet Yok } & \multicolumn{2}{|c|}{ Niyet Var } \\
\hline & & $\mathrm{N}$ & $\%$ & $\mathrm{~N}$ & $\%$ & $\mathrm{~N}$ & $\%$ & $\mathrm{~N}$ & $\%$ \\
\hline \multirow{3}{*}{ Cinsiyet } & Kadın & 25 & 46,3 & 50 & 52,1 & 59 & 47,2 & 16 & 64,0 \\
\hline & Erkek & 29 & 53,7 & 46 & 47,9 & 66 & 52,8 & 9 & 36,0 \\
\hline & Toplam & 54 & 100 & 96 & 100 & 125 & 100 & 25 & 100 \\
\hline \multirow{6}{*}{ Yaş } & $18-23$ & 16 & 29,6 & 10 & 10,4 & 21 & 16,8 & 8 & 32,0 \\
\hline & $24-30$ & 16 & 29,6 & 29 & 30,2 & 34 & 27,2 & 4 & 16,0 \\
\hline & $31-39$ & 8 & 14,8 & 18 & 18,8 & 27 & 21,6 & 2 & 8,0 \\
\hline & $40-45$ & 5 & 9,3 & 20 & 20,8 & 21 & 16,8 & 8 & 32,0 \\
\hline & $45+$ & 9 & 16,7 & 19 & 19,8 & 22 & 17,6 & 3 & 12,0 \\
\hline & Toplam & 54 & 100 & 96 & 100 & 125 & 100 & 25 & 100 \\
\hline \multirow{6}{*}{ Eğitim } & İlköğretim & 7 & 13,0 & 15 & 15,6 & 21 & 16,8 & 8 & 32,0 \\
\hline & Lise & 9 & 16,7 & 20 & 20,8 & 21 & 16,8 & 7 & 28,0 \\
\hline & Ön lisans & 4 & 7,4 & 20 & 20,8 & 22 & 17,6 & 4 & 16,0 \\
\hline & Lisans & 25 & 46,3 & 24 & 25,0 & 36 & 28,8 & 5 & 20,0 \\
\hline & Yüksek lisans & 9 & 16,7 & 17 & 17,7 & 25 & 20,0 & 1 & 4,0 \\
\hline & Toplam & 54 & 100 & 96 & 100 & 125 & 100 & 25 & 100 \\
\hline \multirow{6}{*}{ Gelir } & $0-500$ & 10 & 18,5 & 10 & 10,4 & 14 & 11,2 & 6 & 24,0 \\
\hline & $501-1000$ & 5 & 9,3 & 13 & 13,5 & 16 & 12,8 & 3 & 12,0 \\
\hline & $1001-2000$ & 15 & 27,8 & 28 & 29,2 & 35 & 28,0 & 6 & 24,0 \\
\hline & $2001-3000$ & 12 & 22,2 & 18 & 18,8 & 23 & 18,4 & 4 & 16,0 \\
\hline & $3001+$ & 12 & 22,2 & 27 & 28,1 & 37 & 29,6 & 6 & 24,0 \\
\hline & Toplam & 54 & 1000 & 96 & 100 & 125 & 100 & 25 & 100 \\
\hline
\end{tabular}


Duygusal ölçeğe vermiş oldukları cevaplar doğrultusunda; gülen yüz görseline maruz kalarak satın alma niyeti var sonucuna ulaşılan 150 katılımcının \%52'sinin kadın olduğu, \%30'unun 24-30 yaş aralığında yer aldığı, \%25'inin lisans mezunu olduğu, \%29'unun 10012000 gelir düzeyinde olduğu görülmektedir. Kızgın yüz görseline maruz kalarak satın alma niyeti yok sonucuna ulaşılan 150 katılımcının \%52'sinin erkek, \%27'sinin 24-30 yaş aralığında yer aldığı, \%28'inin lisans mezunu olduğu, \%29'unun 3001+ gelir düzeyinde olduğu görülmektedir.

Tablo 3. Negatif ve Sıcak Duygu Değişkenleri Frekans Analizi

\begin{tabular}{|c|c|c|c|c|c|}
\hline \multirow{2}{*}{\multicolumn{2}{|c|}{ Sıcak Duygu Değişkeni }} & \multirow{2}{*}{\multicolumn{2}{|c|}{$\begin{array}{l}\text { Gülen Yüz Görseli } \\
\text { Hissediyorum/Çok } \\
\text { Hissediyorum }\end{array}$}} & \multirow{2}{*}{\multicolumn{2}{|c|}{$\begin{array}{l}\text { Kızgın Yüz Görseli } \\
\text { Hissediyorum/ Çok } \\
\text { Hissediyorum }\end{array}$}} \\
\hline & & & & & \\
\hline Sicak Duygular & Kodlar & $\mathbf{N}$ & $\%$ & $\mathbf{N}$ & $\%$ \\
\hline İyi & B1 & 118 & 78,7 & 85 & 56,7 \\
\hline Canlı & B2 & 125 & 83,3 & 89 & 59,3 \\
\hline Neşeli & B3 & 86 & 57,3 & 35 & 23,3 \\
\hline Enerjik & B4 & 117 & 78,0 & 77 & 51,3 \\
\hline Mutlu & B5 & 99 & 66,0 & 35 & 23,3 \\
\hline Hareketli & B6 & 126 & 84.0 & 96 & 64,0 \\
\hline Özgür & B7 & 83 & 55,3 & 43 & 28,7 \\
\hline İlgili & B8 & 86 & 57,3 & 47 & 31,3 \\
\hline Ferah & B9 & 89 & 59,3 & 45 & 30,0 \\
\hline Güçlü & B10 & 54 & 36,0 & 23 & 15,3 \\
\hline Zevk Almış & B11 & 95 & 63,3 & 31 & 20,7 \\
\hline Eğlenceli & B12 & 73 & 48,7 & 17 & 88,7 \\
\hline Güvenli & B13 & 48 & 32,0 & 25 & 83,3 \\
\hline Yapic1 & B14 & 70 & 53,3 & 40 & 26,7 \\
\hline Çekici & B15 & 107 & 71,3 & 63 & 42,0 \\
\hline \multirow{2}{*}{\multicolumn{2}{|c|}{ Negatif Duygu Değişkeni }} & \multicolumn{2}{|c|}{ Gülen Yüz Görseli } & \multicolumn{2}{|c|}{ Kızgın Yüz Görseli } \\
\hline & & \multicolumn{2}{|c|}{$\begin{array}{l}\text { Hissediyorum/ Çok } \\
\text { Hissediyorum }\end{array}$} & \multicolumn{2}{|c|}{$\begin{array}{l}\text { Hissediyorum/Çok } \\
\text { Hissediyorum }\end{array}$} \\
\hline Negatif Duygular & Kodlar & $\mathbf{N}$ & $\%$ & $\mathbf{N}$ & $\%$ \\
\hline Kötü & B16 & 5 & 3,3 & 27 & 18,0 \\
\hline Donuk & B17 & 4 & 2,7 & 27 & 18,0 \\
\hline Sinirli & B18 & 1 & 0,7 & 17 & 11,3 \\
\hline Yalnız & B19 & 4 & 2,7 & 16 & 10,7 \\
\hline Kizgin & B20 & 2 & 1,3 & 13 & 8,7 \\
\hline Pişman & B21 & - & - & 10 & 6,7 \\
\hline Küstahça & B22 & 1 & 0,7 & 10 & 6,7 \\
\hline İlgisiz & B23 & 3 & 2,0 & 44 & 29,3 \\
\hline S1kıntılı & B24 & 5 & 3,4 & 29 & 19,3 \\
\hline Şüpheci & B25 & 7 & 4,6 & 33 & 22.0 \\
\hline B1kmış & B26 & 7 & 4,6 & 35 & 23,3 \\
\hline Eleştirel & B27 & 19 & 12,8 & 46 & 30,7 \\
\hline Güvenilmez & B28 & 4 & 2,7 & 28 & 18,7 \\
\hline Karamsar & B29 & 3 & 2.0 & 26 & 17,3 \\
\hline Rahatsız Olmuş & B30 & 2 & 1,4 & 14 & 9,3 \\
\hline
\end{tabular}


Tablo 3'te bilinçaltı mesaj olarak gülen yüz görseline ve kızgın yüz görseline maruz kaldıklarında hissettikleri sıcak duyguların frekans dağılımları görülmektedir. Kızgın yüz görseli yerleştirilmiş bilinçaltı reklam afişini gören katılımcıların hissettikleri sıcak duyguların, gülen yüz görseli yerleşmiş bilinçaltı reklam afişini gören katılımcıların hissettiklerinden daha az sayıda olduğu görülmektedir. Gülen yüz görseli yerleştirilmiş bilinçaltı reklam afişini gören katılımcıların hissettikleri negatif duyguların ise kızgın yüz görseli yerleşmiş bilinçaltı reklam afişini gören katılımcıların hissettiklerinden daha az sayıda olduğu görülmektedir.

Tablo 4. Satın Alma Niyeti Değişkeni

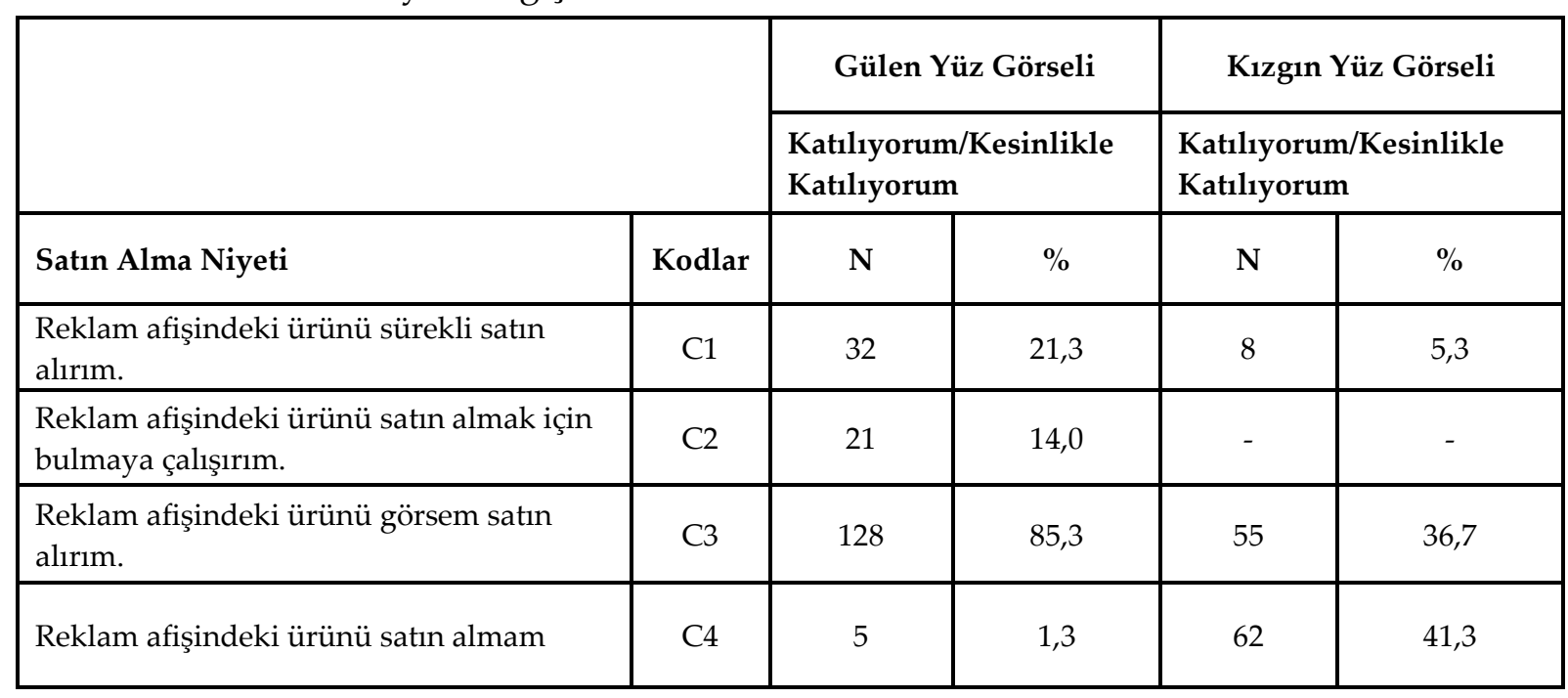

Tablo 4'te gülen yüz ve kızgın yüz görseli yerleştirilmiş reklam afişlerini gören katılımcıların satın alma niyetlerinin frekans dağılımları verilmiştir. Gülen yüz görseli yerleştirilmiş bilinçaltı reklam afişini gören katılımcıların satın alma niyeti gösterdikleri, katılımcıların $\% 85$ 'inin reklam afişindeki ürünü görseler satın alacakları, \%5'inin satın almaya niyeti olmadıkları ortaya çıkmıştır. Kızgın yüz görseli yerleştirilmiş bilinçaltı reklam afişini gören katılımcılarda ise satın alma niyetinin çok daha az olduğu, katılımcıların \%36,7'sinin reklam afişindeki ürünü görse satın alacağ1 ancak \%41,3'ünün reklam afişindeki ürünü satın almayacağı sonucu ortaya çıkmıştır.

Çalışmada kullanılan bir diğer analiz ise bağımsız değişkenler ile bağımlı değişken arasındaki nedensellik ilişkisini inceleyen nominal lojistik regresyon analizidir. Analizin kullanım amacı en az değişken ile sonuç değişkeni ve açıklayıcı değişkenler arasındaki ilişkiyi tanımlayan kabul edilebilir modeli kurmaktır (Altın, Aktaş ve Erkuş, 2009; 126). Çalışmada kurulan model, satın alma niyeti skoru $\geq 0,50$ olan tüketicilerin (niyet var=1), satın alma niyeti skoru $<0,50$ olanların ise satın alma niyetinde olmadıkları (niyet yok=0) şeklinde kodlanmıştır.

Yapılan analiz sonucunda gülen yüz görseli yerleştirilen bilinçaltı reklamın satın alma niyetine etkisi üzerine tahmin edilen değerin \%64 oranında satın alma niyetine olumlu etkisi vardır. Tablo 5'e göre modelin açıklayıcılık düzeyini gösteren Nagelkerke R Kare değeri 0,47>0,30 olduğu için; model orta düzeyde açıklayıcıdır şekilde ifade edebilmektedir. 
Hosmer and Lemeshow testinde anlamlılık değeri $0,27>0,05$ olduğuna göre; tahmin edilen değer ile gerçek değer arasında anlamlı bir farklılık yoktur.

Tablo 5. Gülen Yüz Görseli Yerleştirilen Bilinçaltı Reklamın Satın Alma Niyetini Açıklayıcılığ 1 ve Anlamlılığ

\begin{tabular}{|c|c|c|}
\hline \multicolumn{2}{|c|}{ Hosmer ve Lemeshow Testi } & R Kare \\
\hline Ki Kare & Anlamlılık & Açıklayıcılık \\
\hline 9,893 &, 273 &, 472 \\
\hline
\end{tabular}

Kızgın yüz görseli yerleştirilen bilinçaltı reklamın satın alma niyetine etkisi üzerine tahmin edilen değerin \%83,3 oranında satın alma niyetine olumsuz yönde etkisi vardır. Tablo 6'ya göre Nagelkerke R Kare değeri 0,49>0,30 olduğu için; model orta düzeyde açıklayıcıdır. Hosmer and Lemeshow testinde anlamlılık değeri ise 0,094>0,05 olduğuna göre; tahmin edilen değer ile gerçek değer arasında anlamlı bir farklılık yoktur.

Tablo 6. Kızgın Yüz Görseli Yerleştirilen Bilinçaltı Reklamın Satın Alma Niyetini Açıklayıcılığı ve Anlamlılı̆̆ı

\begin{tabular}{|c|c|c|}
\hline \multicolumn{2}{|c|}{ Hosmer ve Lemeshow Testi } & R Kare \\
\hline Ki Kare & Anlamlılık & Açılayıc1lık \\
\hline 13,562 &, 094 &, 497 \\
\hline
\end{tabular}

Aşağıda Tablo 7 ve Tablo 8'de gösterilen parametrik kodlama kısmında ise değişkenlerin aralarındaki ilişkiyi açıklamada hangi grupların referans olarak alınacakları görülmektedir. Tüm değerleri ",000" olan değişkenler referans değişkenlerdir. Yine tabloda yer alan anlamlılık kısmında, değişkenlerin değeri $<0,05$ olduğu takdirde satın alma niyetine anlamlı bir etkisi vardır denilmektedir.

Tablo 7'de gülen yüz görseli yerleştirilmiş bilinçaltı reklam afişinin gösterildiği tüketicilerin demografik özelliklerinden cinsiyet ve gelir düzeyinin satın alma niyetine anlamlı bir etkisi görülmezken, yaş ve eğitim düzeyindeki artışın tüketicilerin satın alma niyetlerinde azalışa sebep olduğu görülmüştür. Biel ve Bridgewater (1990) ve Biel (2004) yapmış oldukları araştırmada, bir reklamı çok beğenen insanların ikna olma olasılığının reklama karşı nötr olan insanlardan iki kat fazla olduğu sonucuna varmışlardır. Ayrıca, Weilbach'a (2003) göre bir reklamın tüketiciyi etkileyebilmesi için bireyin o reklamda kendinden bir şeyler bulması gerekmektedir ve reklamı gördügüünde mutlu olması gerekmektedir. Tablo 7'de görüldüğü gibi, sıcak duygu değişkenin tüketicilerin satın alma niyetine olumlu yönde etkisini ortaya koyan gerçekleşen değer \%81 olup, yapılan araştırmaları destekler niteliktedir. 
Tablo 7. Gülen Yüz Görseli Yerleştirilen Bilinçaltı Reklamda Değişkenlerin Satın Alma Niyetine Etkisi

\begin{tabular}{|c|c|c|c|c|c|c|c|c|c|}
\hline \multirow{2}{*}{\multicolumn{2}{|c|}{ Demografik Değişkenler }} & \multirow{2}{*}{$\mathbf{N}$} & \multirow{2}{*}{ Kesen } & \multicolumn{4}{|c|}{ Parametrik Kodlama } & \multirow{2}{*}{ Anlamlılık } & \multirow{2}{*}{$\begin{array}{c}\text { Etkileyen } \\
\text { Kuvvet }\end{array}$} \\
\hline & & & & (1) & $(2)$ & (3) & (4) & & \\
\hline \multirow{6}{*}{$\begin{array}{l}\text { Gelir } \\
\text { Gelir } 1 \\
\text { Gelir } 2 \\
\text { Gelir } 3 \\
\text { Gelir } 4 \\
\text { Gelir } 5\end{array}$} & \multicolumn{9}{|c|}{242} \\
\hline & $0-500$ & 20 &,- 053 & 1,000 & ,000 & ,000 & ,000 & ,950 & ,948 \\
\hline & $501-1000$ & 18 &,- 022 & ,000 & 1,000 & ,000 & ,000 & 982 & 978 \\
\hline & $1001-2000$ & 43 & $-1,181$ & ,000 & ,000 & 1,000 & ,000 & ,081 & ,307 \\
\hline & $2001-3000$ & 30 & $-1,223$ & ,000 & ,000 & ,000 & 1,000 & ,077 & ,294 \\
\hline & $3001+$ & 39 & & 000 & ,000 & ,000 & 000 & & \\
\hline \multicolumn{10}{|c|}{$\begin{array}{ll}\text { Toplam } & 150 \\
\end{array}$} \\
\hline \multirow{6}{*}{$\begin{array}{l}\text { Yaş } \\
\text { Yaş } 1 \\
\text { Yaş } 2 \\
\text { Yaş } 3 \\
\text { Yaş } 4 \\
\text { Yaş } 5 \\
\end{array}$} & \multicolumn{9}{|c|}{,003 } \\
\hline & $18-23$ & 26 & $-2,865$ & 1,000 & ,000 & ,000 & ,000 & ,001 & ,057 \\
\hline & $24-30$ & 45 &,- 312 & ,000 & 1,000 & ,000 & ,000 & ,652 & ,732 \\
\hline & $31-39$ & 26 &,- 538 & ,000 & 000 & 1,000 & ,000 & ,495 & ,584 \\
\hline & $40-45$ & 25 & 1,128 & ,000 & ,000 & 000 & 1,000 & ,177 & 3,090 \\
\hline & $45+$ & 28 & & , 000 & , 000 & , 000 & ,000 & & \\
\hline \multicolumn{10}{|l|}{ Toplam } \\
\hline \multirow{6}{*}{$\begin{array}{l}\text { Eğitim } \\
\text { Eğitim } 1 \\
\text { Eğitim } 2 \\
\text { Eğitim } 3 \\
\text { Eğitim } 4 \\
\text { Eğitim } 5\end{array}$} & \multicolumn{9}{|c|}{019} \\
\hline & İlköğretim & 22 & ,212 & 1,000 & ,000 & ,000 & 000 & 819 & 1,236 \\
\hline & Lise & 29 &,- 070 & ,000 & 1,000 & ,000 & ,000 & ,933 & ,932 \\
\hline & Ön Lisans & 24 & 1,216 & ,000 & ,000 & 1,000 & ,000 & 196 & 3,374 \\
\hline & Lisans & 49 & $-1,303$ & ,000 & ,000 & ,000 & 1,000 & ,052 & 272 \\
\hline & Lisansüstü & 26 & & ,000 & ,000 & ,000 & ,000 & & \\
\hline \multicolumn{10}{|c|}{$\begin{array}{ll}\text { Toplam } & 150\end{array}$} \\
\hline \multirow{3}{*}{$\begin{array}{l}\text { Cinsiyet } \\
\text { Cinsiyet1 } \\
\text { Cinsiyet2 }\end{array}$} & \multicolumn{9}{|c|}{840} \\
\hline & Kadın & 75 & ,097 & 1,000 & & & & & 1,102 \\
\hline & Erkek & 75 & &, 000 & & & & & \\
\hline \multicolumn{10}{|c|}{$\begin{array}{lc}\text { Toplam } & 150\end{array}$} \\
\hline \multicolumn{10}{|c|}{ Duygu Değişkenleri } \\
\hline \multicolumn{2}{|c|}{ Sicak Duygular } & 150 & 1,581 & & & & & 001 & 4,858 \\
\hline \multicolumn{2}{|c|}{ Satın Alma Niyeti } & \multicolumn{2}{|c|}{ Var } & \multicolumn{4}{|l|}{ Yok } & \multicolumn{2}{|l|}{$\%$} \\
\hline \multicolumn{2}{|c|}{ Var } & \multicolumn{2}{|c|}{39} & \multicolumn{4}{|l|}{15} & \multicolumn{2}{|l|}{72,2} \\
\hline Yok & & 13 & & 83 & & & & 86,5 & \\
\hline Toplam & & & & & & & & & \\
\hline
\end{tabular}

Tablo 8' de kızgın yüz görseli yerleştirilmiş bilinçaltı reklam afişinin gösterildiği tüketicilerin demografik özelliklerinden hiçbirisinin tüketicilerin satın alma niyetlerine anlamlı etkilerinin bulunmadığ tespit edilmiştir. 
Tablo 8. Kızgın Yüz Görseli Yerleştirilen Bilinçaltı Reklamda Değişkenlerin Satın Alma Niyetine Etkisi

\begin{tabular}{|c|c|c|c|c|c|c|c|c|c|}
\hline \multirow{2}{*}{\multicolumn{2}{|c|}{ Demografik Değişkenler }} & \multirow{2}{*}{$\mathbf{N}$} & \multirow{2}{*}{ Kesen } & \multicolumn{4}{|c|}{ Parametrik Kodlama } & \multirow{2}{*}{ Anlamlılık } & \multirow{2}{*}{$\begin{array}{c}\text { Etkileyen } \\
\text { Kuvvet }\end{array}$} \\
\hline & & & & (1) & $(2)$ & (3) & (4) & & \\
\hline \multirow{6}{*}{$\begin{array}{l}\text { Gelir } \\
\text { Gelir } 1 \\
\text { Gelir } 2 \\
\text { Gelir } 3 \\
\text { Gelir } 4 \\
\text { Gelir } 5\end{array}$} & & & \multicolumn{7}{|c|}{,907 } \\
\hline & $0-500$ & 20 &,- 383 & 1,000 & ,000 & ,000 & 000 & 719 & ,682 \\
\hline & $501-1000$ & 19 &,- 170 & 000 & 1,000 & ,000 & 000 & 896 & 844 \\
\hline & $1001-2000$ & 41 &,- 831 & 000 & 000 & 1,000 & 000 & 428 & ,435 \\
\hline & $2001-3000$ & 27 &,- 081 & ,000 & ,000 & ,000 & 1,000 & ,933 & 1,084 \\
\hline & $3001+$ & 43 & & , 000 & ,000 &, 000 & ,000 & & \\
\hline \multicolumn{10}{|l|}{ Toplam } \\
\hline \multirow{6}{*}{$\begin{array}{l}\text { Yaş } \\
\text { Yaş } 1 \\
\text { Yaş } 2 \\
\text { Yaş } 3 \\
\text { Yaş } 4 \\
\text { Yaş } 5\end{array}$} & \multicolumn{9}{|c|}{,136 } \\
\hline & $18-23$ & 29 & 2,074 & 1,000 & ,000 & ,000 & 000 & ,092 & 7,958 \\
\hline & $24-30$ & 38 & 1,210 & 000 & 1,000 & 000 & 000 & 328 & 3,353 \\
\hline & $31-39$ & 29 &,- 368 & 000 & ,000 & 1,000 & ,000 & ,760 & 692 \\
\hline & $40-45$ & 29 & 1,784 & ,000 & 000 & 000 & 1,000 & 098 & 5,955 \\
\hline & $45+$ & 25 & & 000 & 000 & 000 & 000 & & \\
\hline \multicolumn{10}{|l|}{ Toplam } \\
\hline \multirow{6}{*}{$\begin{array}{l}\text { Eğitim } \\
\text { Eğitim } 1 \\
\text { Eğitim } 2 \\
\text { Eğitim } 3 \\
\text { Eğitim } 4 \\
\text { Eğitim } 5\end{array}$} & \multicolumn{9}{|c|}{ 148 } \\
\hline & İlköğretim & 29 & 1,581 & 1,000 &, 000 & ,000 & 000 & ,053 & 21,428 \\
\hline & Lise & 28 & 1,520 & ,000 & 1,000 & ,000 & ,000 & ,011 & 47,062 \\
\hline & Ön Lisans & 26 & 1,509 & 000 & ,000 & 1,000 & ,000 & ,093 & 12,599 \\
\hline & Lisans & 41 & 1,340 & ,000 & ,000 & 000 & 1,000 & 071 & 11,260 \\
\hline & Lisansüstü & 26 & & ,000 & ,000 & ,000 & ,000 & & \\
\hline \multicolumn{10}{|c|}{150} \\
\hline \multirow{3}{*}{$\begin{array}{l}\text { Cinsiyet } \\
\text { Cinsiyet1 } \\
\text { Cinsiyet2 }\end{array}$} & \multicolumn{9}{|c|}{,380 } \\
\hline & Kadın & 75 & ,538 & 1,000 & & & & & 1,713 \\
\hline & Erkek & 75 & & 000 & & & & & \\
\hline \multicolumn{10}{|c|}{ Toplam 300} \\
\hline \multicolumn{10}{|c|}{ Duygu Değişkenleri } \\
\hline \multicolumn{2}{|c|}{ Negatif Duygular } & 150 & $-2,475$ & & & & & ,000 & ,084 \\
\hline \multicolumn{2}{|c|}{ Satın Alma Niyeti } & \multicolumn{2}{|l|}{ Yok } & \multicolumn{4}{|l|}{ Var } & \multicolumn{2}{|l|}{$\%$} \\
\hline \multicolumn{2}{|c|}{ Yok } & \multicolumn{2}{|l|}{121} & \multicolumn{4}{|l|}{4} & \multicolumn{2}{|l|}{96,8} \\
\hline Var & & 10 & & 15 & & & & 60,0 & \\
\hline Toplam & & & & & & & & & \\
\hline
\end{tabular}

Rahatsız edici reklam izleyiciyi kışkırtır, onda hoşnutsuzluk ve geçici sabırsızlık yaratır. Bu tür reklamlara aynı zamanda sinirlendirici reklam da denmektedir. Adından da anlaşılacağ üzere bu tür reklamlar tüketicinin olumsuz duygu ve düşüncelerini toplarken, ürüne karş1 olan ilgi ve sempatisini azaltır (Çakır ve Çakır, 2007: 42). Sonucu desteklemek adına, kızgın yüz görseli yerleştirilmiş bilinçaltı reklamın tüketicilerin satın alma niyetine etkisine dair negatif duygu değişkeninin açıklayıcılık ve anlamlılık analizi (bkz. Tablo 6) yapılmış, yapılan analiz soncunda değişkenin, tüketicilerin satın alma niyetini olumsuz yönde etkilediği sonucunu doğrulanmıştır. Yine Çakır'a (2007) göre, tüketici reklamların bilgilendirici olduğuna ve mutlu ettiğine inanıyorsa reklama karşı genel algı da olumlu olmaktadır. Yani reklama karşı genel bir kanı oluşurken, rahatsız edicilik unsuru, bilgilendiricilik ve mutluluk unsurları kadar önemli değildir. Tüketici reklamlardan rahatsızlık duysa bile, şayet reklam 
sayesinde bilgileniyor ya da mutlu oluyorsa reklamlara karşı genel bakışı da olumlu olmaktadır demektedir. Tablo 8 'de ise negatif duygu değişkeninin tüketicilerin satın alma niyetine olumsuz yönde etkisini ortaya koyan gerçekleşen değer \%90 olarak bulunmuştur. Yapılan araştırmaların aksine, söz konusu bilinçaltı reklam ise rahatsız edici unsurların tüketiciyi yüksek oranda olumsuz etkilediği görülmektedir.

\section{SONUÇ VE ÖNERILLER}

Günümüzde işletmeler rakiplerinden önde olabilmek adına reklam uygulamalarına fazlasıyla önem vermektedirler. Reklam konusunda kullanmış oldukları yöntemleri teknolojiden yardım alarak geliştirmektedirler. Bunu yaparken de tüketicilerin satın alma niyetleri, tutum ve davranışlarına etki eden faktörleri belirleyebilmek adına, psikoloji, sosyoloji ve nöroloji gibi reklam ile ilgili dallardan yararlanmaktadırlar. Bu alanlarda yapilan çalışmaları inceleyerek tüketicilerin nelerden etkilenebileceklerini, korkularını, hayallerini, amaçlarını, nasıl mutlu hissedeceklerini, neleri sevip nelerden nefret ettiklerini, isteklerini, ihtiyaçlarını, zihinlerinde var olan ama kendilerinin dahi farkında olmadıkları bilinçaltındaki derinlikleri öğrenmeye çalışmaktadırlar. Elde edilen bilgiler doğrultusunda da tüketicilere doğrudan ya da dolaylı mesajlar yollayarak tercihlerine yön vermeye çalışmaktadırlar.

Bilinçaltı reklamcılık böyle bir sürecin içerisinde var olmuş bir pazarlama iletişim aracıdır. Günümüzde, rakiplerinden farklılaşarak hedef kitlenin kendilerini tercih etmesini sağlamaya çalışan işletmelerin en gözde iletişim yönteminin bilinçaltı reklamcılık olduğu konuşulmaktadır. Her ne kadar reklamcılar tarafından uygulandığı kabul edilmese de, geliştirilen cihazlar tarafından reklam örnekleri incelenmekte ve bilinçaltı reklamcılığın var olduğu düşünülmektedir.

Çalışmada, bilinçaltı reklamcılığın tüketicilerin satın alma niyetine etkisi varsa ne düzeyde olduğu, etki eden faktörlerin neler olabileceği, tüketicilerin özellikleri ve duygu değişkenine göre farklılıklarının ne şekilde olduğu ortaya konmaya çalışılmaktadır. Özel olarak hazırlanan reklam afişinin iki kopyası alınmış; birisine tüketicilerin satın alma niyetini olumlu yönde etkileyip etkilemeyeceğini ölçmek amaçlı gizli mesaj olarak gülen yüz, diğerine ise tüketicilerin satın alma niyetini olumsuz yönde etkileyip etkilemeyeceğini ölçmek amaçlı gizli mesaj olarak kızgın yüz görseli yerleştirilmiştir.

Gülen yüz görseli yerleştirilen bilinçaltı reklam afişinin gösterildiği katılımcılara bakıldığında; 18-23 yaş aralığındaki tüketicilerin bilinçaltı reklamdan daha fazla etkilendikleri, yaştaki \%1'lik artışı 0,057 kat oranında daha az satın alma niyeti gösterilmesine sebep olduğu görülmüştür. Eğitim düzeyindeki \%1'lik artışın da 0,272 kat oranında daha az satın alma niyeti gösterilmesine sebep olduğu görülmüştür. Dolayısıyla şirketler, bilinçaltı reklam ile tüketicilerin satın alma niyetini olumlu yönde etkilemek istiyorlarsa, genç ve eğitim düzeyi orta dereceli tüketici kesimini hedef almaları önerilebilir. Ayrıca bu çalışma göstermiştir ki, şirketler hazırlayacakları bilinçaltı reklam ile tüketicinin satın alma niyetini olumlu yönde etkilemek istiyorlarsa; iyi, canlı, enerjik, mutlu, hareketli, yapıcı, çekici, ferah, özgür ve zevk almış duygularını uyarmayı tercih etmelidirler. Bu konuda stratejiler geliştirmeli, tüketicileri iyi hissettirecek imge ya da arketipleri araştırmalıdırlar. 
Kızgın yüz görseli yerleştirilen bilinçaltı reklam afişinin gösterildiği katılımcılara bakıldığında demografik özelliklerin hiçbirisinin tüketicilerin satın alma niyetine etkisi bulunmamaktadır. Demografik özelliklerin aksine, tüketicilerde negatif duygular yüksek oranda uyarılmış ve katılımcıların afişte gösterilen ürüne karşı satın alma niyetleri olumsuz yönde etkilenmiştir. Çalışma sonuçlarından yola çıkarak şirketler tüketicilerin; kötü, donuk, sinirli, yalnız, kızgın, pişman, küstahça, ilgisiz, sıkıntılı, şüpheci, bıkmış, eleştirel, güvenilmez, karamsar ve rahatsız olmuş duygularını harekete geçirmek istemiyorlarsa bilinçaltı reklam hazırlarken kızgın yüz görseli kullanmamalıdırlar. Tüketicilerin negatif duygularını etkileyecek herhangi bir imgeden, arketipten özellikle kaçınmaları önerilmektedir. Çünkü çalışma göstermiştir ki, sıcak duyguların negatif duygulara oranla satın alma niyetlerini etkileme gücü daha yüksektir.

Çalışma sonucunda satın alma niyetine etkisi kanıtlanmış olan bilinçaltı reklamcılık için; ihtiyaç yaratılarak ve arzu uyandırılarak oluşturulan "tüketim toplumu" kavramının sebeplerinden birisidir diyebiliriz. Küçük yaşlardan başlayarak sosyal medya ve kitle iletişim araçları tarafından bilinçaltımıza yollanan mesajlar uzun süreli bellekte saklanmakta ve tüketici olarak satın alma niyetimize yön vermektedir. Hiçbir şekilde farkında olamadığımız bu durum ile ilgili tüketiciler olarak farkındalığımızın artması için bilinçaltı kavramı ve bilinçaltı reklam kavramlarının araştırılması gerekmektedir. İnsan psikolojisi ve davranışları hassas konular olmakla birlikte, tüketicilerin günlük sıradan kararlarını bile etkileyebilecek sıklıkta karşılaştığı bilinçaltı mesajlarından ve reklamlardan yasal açıdan korunması önerilmektedir.

Araştırmada satın alma niyetini etkileyecek iki tane bağımsız değişken incelenerek literatüre katkı sağlanmış olsa da, zaman, maliyet ve materyal kısıtı nedeniyle farklı analiz yöntemleri, farklı kesimdeki insanlar ve diğer bilinçaltı reklam araçları araştırma kapsamının dışında bırakılmıştır. Dolayısıyla gelecek çalışmalarda diğer bilinçaltı yöntemlerin kullanılmasının literatüre zenginlik kazandıracağı düşünülmektedir.

\section{KAYNAKÇA}

Altın, A., Aktaş, R., \& Erkuş-Duman E. (2009). On A Multivariable Extension for the Extended Jacobi Polynomials. J. Math. Anal. Appl., 353(1), 121-133.

Biel, A. L., \& Bridgewater, C. A. (1990). Attributes of Likeable Television Commercials. Journal of Advertising Research, 30(3), 38-44.

Biel, A. L. (2004). Sevimlilik: Neden Sevilen Reklamlar Daha Çok Satar, Reklam Nasıl İşe Yarar: Araştırmanın Rölü. Der: John Philip Jones, Çev: Mustafa Dilber, Didem Ünal Biçicioğlu, İstanbul: Reklamcılık Vakfı Yayınları.

Bilen, İ. (2013). Bilinçaltınız Elimizde. Malatya: Bilsam Yayınları.

Borça, G. (2013). Marka Sunumu, İndirilme tarihi: 14 Mayıs 2016, URL: http://www.markam.biz/icerik-marka-sunumu-23.html 
Cüceloğlu, D. (2012). İnsan ve Davranışı: Psikolojinin Temel Kavramları. İstanbul: Remzi Kitapevi.

Çakır, V. ve Çakır, V. (2007). Televizyon Reklamlarının Algılanan Değeri ve Reklam Tutumu İlişkisi: Bir Yapısal Eşitlik Modeli. İstanbul Üniversitesi İletişim Fakültesi Dergisi, 0(30), 37-58

Darıcı, S. (2013). Bilinçaltı Reklamcılık ve İletişim Teknikleri, İstanbul: İstabul Gelişim Üniversitesi Yayınları.

Dobrenkov, V. I. (1979). Eric Fromm'un ve Yeni Freudculuğun Eleştirisi. Çev: Dr. Oya Tangör Levent Küey, İstanbul: Sorun Yayınları.

Edell, J. A., \& Burke, M. C. (1987). The Power of Feelings in Understanding Advetising Effects. Journal of Consumer Research, 14(3), 421-433.

Fordham, F. (2015). Jung Psikolojisinin Ana Hatları, Çev: Yalçıner, A., Ankara: Say Yayınları.

İnceoğlu, M. (1993). Tutum Algı İletişim. Ankara: Verso Yayıncılık.

Kağıtçıbaşı, Ç. (1988). İnsan ve İnsanlar. İstanbul: Evrim Basım Yayım.

Kapar, S. (2009). Resimde Sembolik İmgelemi Oluşturan Psikolojik Etkenler, Atatürk Üniversitesi Güzel Sanatlar Fakültesi Dergisi/Journal Of Fine Arts Faculty, 0(15), 43-46.

Koç, E. (2013). Tüketici Davranışları ve Pazarlama Stratejileri. Ankara: Global Yerel Yaklaşım, Seçkin Yayıncılık.

Kotler, P. (1997). Marketing Management, Analysis, Planning, Implementation and Control. New Jersey: Prentice Hall International Inc., 9th Ed.

Küçükbezirci, Y. (2013). Bilinçaltı Mesaj Gönderme Teknikleri Ve Bilinçaltı Mesajların Topluma Etkileri. International Periodical For The Languages, Literature and History of Turkish, 8(9),1879-1894.

Moriarty, S. E. (1991). Creative Advertising. New Jersey: Prince Hall.

Morris, J. D. (1995). Observation: SAM: The Self-Assessment Manikin; An Efficient CrossCultural Measurement of Emotional Response. Journal of Advertising Research, 35(6), 63-68.

Soh, H. (2009). Measuring Trust İ Ad. Development and Validation Of The Adtrust Scale. Journal Of Advertising, 38(2), 83-103.

Stafford, M. R. (1998). Advertising Sex-Typed Services: The Effects of Sex, Service Type, and Employee Type on Consumer Attitudes. Journal of Advertising, 27(2), 65-82.

Sungur, S. (2007). Bilinçaltı Reklamcılık ve Toplumsal Etkileri, İstanbul Üniversitesi İletişim Fakültesi dergisi, 29(1), 169-182.

Tek, Ö. B. (1999). Pazarlama İlkeleri: Global Yönetimsel Yaklaşım Türkiye Uygulamaları. İstanbul: Beta Yayınları.

Tokol, T. (1994). Pazarlama Yönetimi. Bursa: Uludağ Üniversitesi.

Türkkan, R. O. (2000). İkna ve Uzlaşma Sanatı. İstanbul: Altın Kitaplar. 
Uztuğ, F. (2003). Markan Kadar Konuş Marka İletişimi Stratejileri. İstanbul: MediaCat Kitapları.

Weilbach, W. W. (2003). How Advertising Affects Consumers, Journal of Advertising Research, 43(2) , 230-234.

Yükselen, C. (2003). Pazarlama İlkeler-Yönetim-Örnek Olaylar. Ankara: Detay Yayıncılık.

EK-1. Gülen Yüz Görseli Yerleştirilmiş Bilinçaltı Reklam Afişi

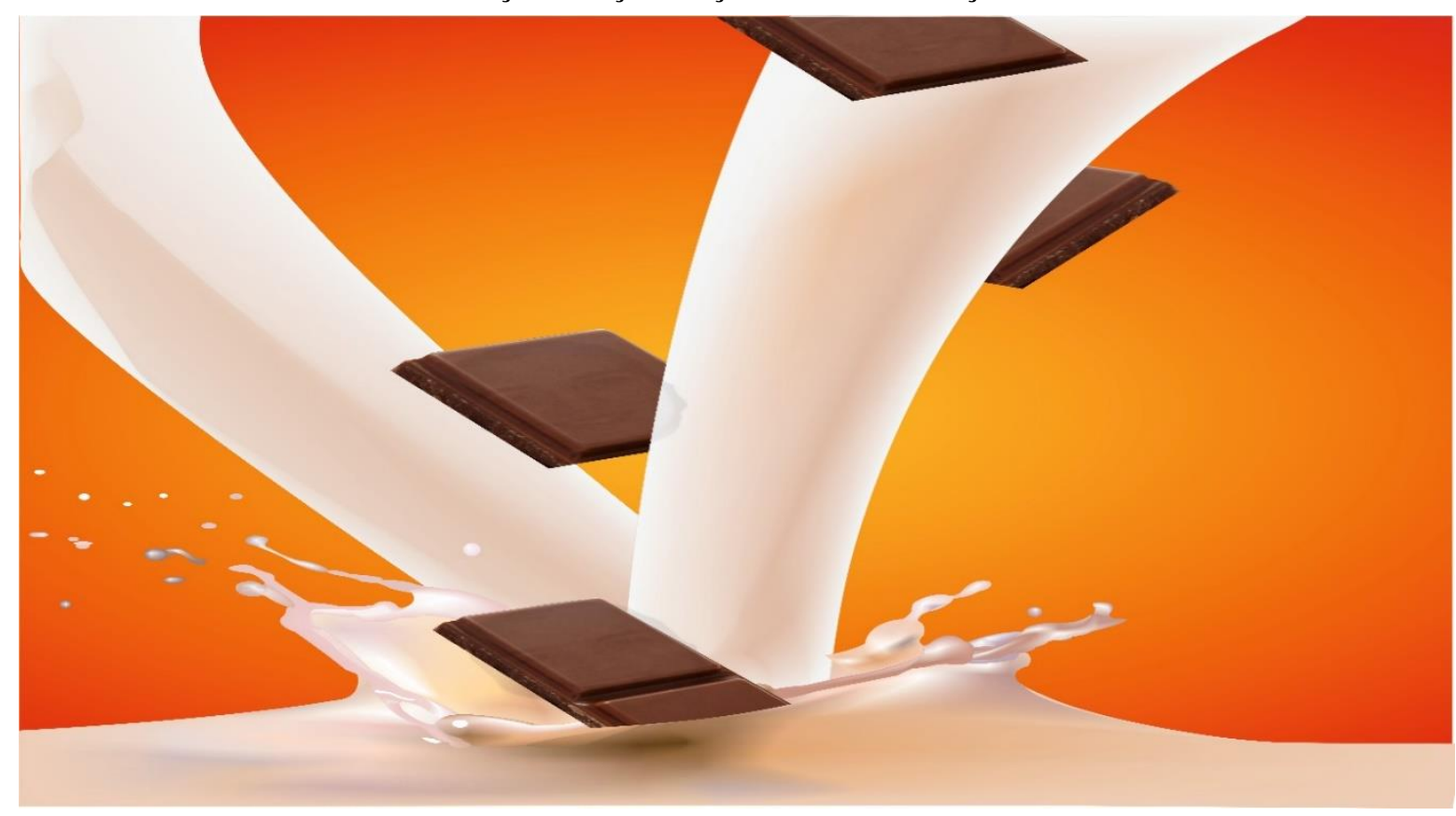

EK-2. Kızgın Yüz Görseli Yerleştirilmiş Bilinçaltı Reklam Afişi

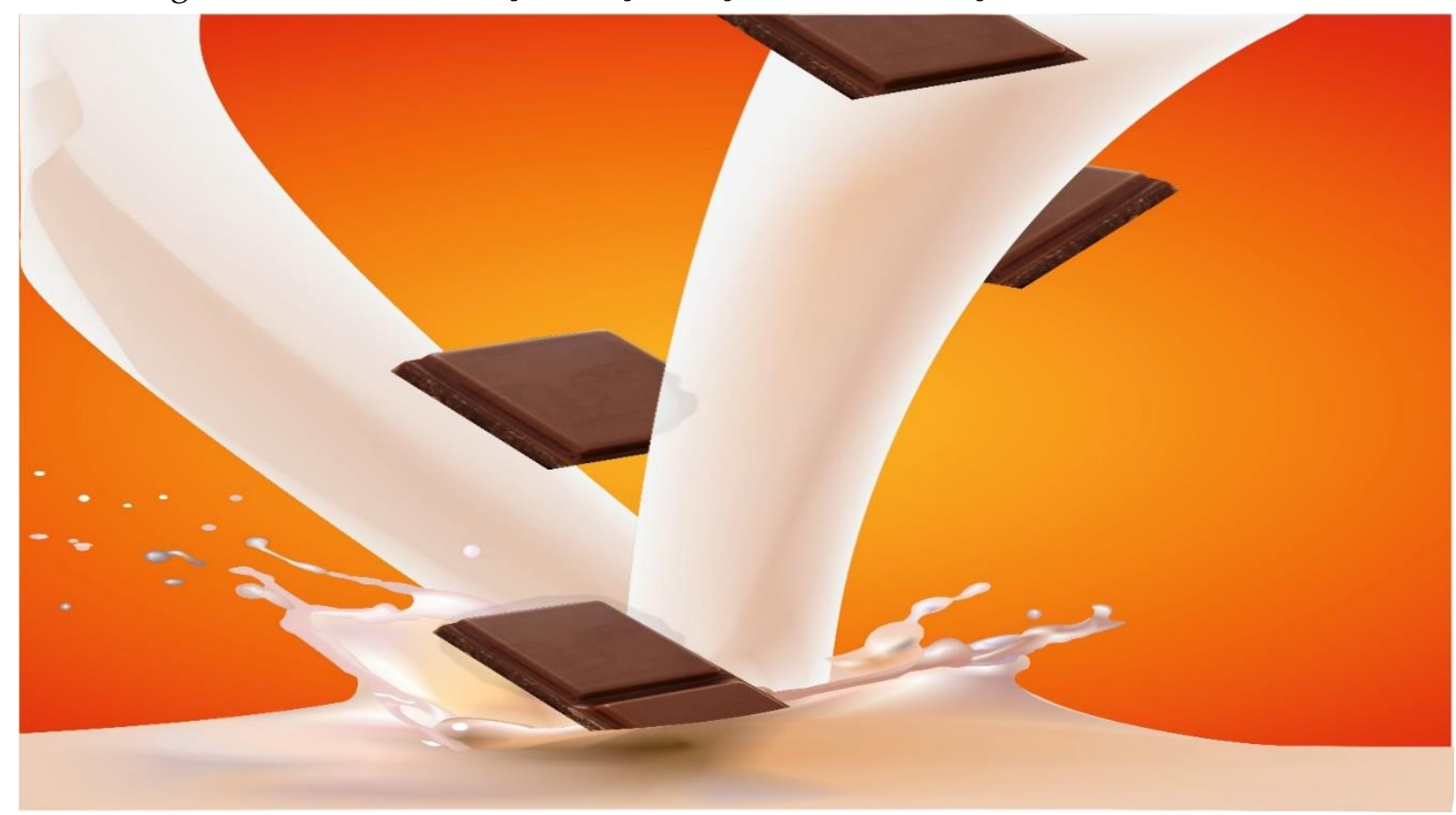




\section{EK-3. Anket Formu}

A. Demografik Sorular

Cinsiyetiniz:

1( ) Kadın 2( ) Erkek

Yaşınız:

1 ( ) 18-23 2 ( ) 24-30 3 ( ) 31-39 $\quad 4$ ( ) $40-45 \quad 5$ ( ) $45+$

Eğitim Durumunuz:

1 ( ) Illköğretim 2( ) Lise $\quad 3($ ) Önlisans $\quad 4$ ( ) Lisans $\quad 5$ ( ) Lisans Üstü

Gelir Düzeyiniz:

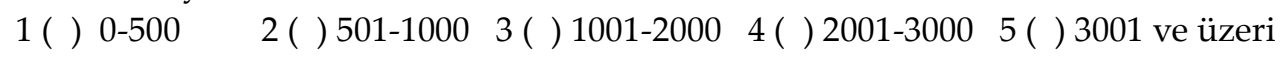

B. Az önce görmüş olduğunuz reklam afişini düşünerek şıklardan yalnızca birine çarpı işareti $(X)$ koyunuz ve lütfen boş madde bırakmadan cevaplayınız.

\begin{tabular}{|c|c|c|c|c|c|c|}
\hline Kod & İfadeler & $\begin{array}{l}\text { Hiç } \\
\text { hissetmiyorum }\end{array}$ & Hissetmiyorum & $\begin{array}{l}\text { Fikrim } \\
\text { Yok }\end{array}$ & Hissediyorum & $\begin{array}{l}\text { Çok } \\
\text { hissediyorum }\end{array}$ \\
\hline B1 & $\dot{\text { İyi }}$ & & & & & \\
\hline B2 & Canlı & & & & & \\
\hline B3 & Neşeli & & & & & \\
\hline B4 & Enerjik & & & & & \\
\hline B5 & Mutlu & & & & & \\
\hline B6 & Hareketli & & & & & \\
\hline B7 & Özgür & & & & & \\
\hline B8 & İlgili & & & & & \\
\hline B9 & Ferah & & & & & \\
\hline B10 & Güçlü & & & & & \\
\hline B11 & Zevk almış & & & & & \\
\hline B12 & Eğlenceli & & & & & \\
\hline B13 & Güvenli & & & & & \\
\hline B14 & Yapic1 & & & & & \\
\hline B15 & Çekici & & & & & \\
\hline B16 & Kötü & & & & & \\
\hline B17 & Donuk & & & & & \\
\hline B18 & Sinirli & & & & & \\
\hline B19 & Yalnız & & & & & \\
\hline B20 & Kizgin & & & & & \\
\hline B21 & Pişman & & & & & \\
\hline B22 & Küstahça & & & & & \\
\hline B23 & İlgisiz & & & & & \\
\hline B24 & Sikıntılı & & & & & \\
\hline B25 & Şüpheci & & & & & \\
\hline B26 & Bikmış & & & & & \\
\hline B27 & Eleştirel & & & & & \\
\hline B28 & Güvenilmez & & & & & \\
\hline B29 & Karamsar & & & & & \\
\hline $\mathrm{B} 30$ & Rahatsız olmuş & & & & & \\
\hline
\end{tabular}




\section{EK-3. (Devamı)}

C. Az önce görmüş olduğunuz reklam afişini düşünerek şıklardan yalnızca birine çarpı işareti (X) koyunuz ve lütfen boş madde bırakmadan cevaplayınız.

\begin{tabular}{|c|c|c|c|c|c|c|}
\hline Kod & İfadeler & $\begin{array}{l}\text { Kesinlikle } \\
\text { Katılmıyorum }\end{array}$ & Katılmiyorum & $\begin{array}{l}\text { Fikrim } \\
\text { Yok }\end{array}$ & Katıliyorum & $\begin{array}{l}\text { Kesinlikle } \\
\text { Katıliyorum }\end{array}$ \\
\hline C1 & $\begin{array}{l}\text { Reklam afişindeki ürünü } \\
\text { sürekli satın alırım. }\end{array}$ & & & & & \\
\hline $\mathrm{C} 2$ & $\begin{array}{l}\text { Reklam afişindeki ürünü } \\
\text { satın almak için bulmaya } \\
\text { çalışırım. }\end{array}$ & & & & & \\
\hline $\mathrm{C} 3$ & $\begin{array}{l}\text { Reklam afişindeki ürünü } \\
\text { görsem satın alırım. }\end{array}$ & & & & & \\
\hline $\mathrm{C} 4$ & $\begin{array}{l}\text { Reklam afişindeki ürünü } \\
\text { satın almam. }\end{array}$ & & & & & \\
\hline
\end{tabular}

